\title{
A CRITICAL REVIEW OF THE ROMAN ATRIUM HOUSE: READING THE MATERIAL EVIDENCE ON “ATRIUM" (1)
}

\author{
Kemal Reha KAVAS
}

Received: 17.06.2010; Final Text: 21.06.2012

Keywords: atrium; Roman residential architecture; space layout; roofing; architectural historiograph; Pompei.

1. The initial phase of this research has been done in AH 521 (Themes on Ancient Domestic Architecture, Instructor of the Course: Assoc.Prof. Dr. Lale Özgenel, Graduate Program of Architectural History, METU, Ankara, Turkey, 2007-2008 Academic Year Fall Term, Ph.D.)

2. Atrium is the common central space around which the other rooms of the dwelling are organized. Atrium has a central importance in the physical fabric of Pompeii and Herculaneum which provide the most substantial information about Roman domestic architecture because it is the space which typifies the dwelling unit of a Roman single family. This is why the typical Roman house is named after this central space.

3. Riggsby (1998, 37-56) defines this approach as "architecturally-derived model" of the atrium-house.

4. Using a similar terminology, Arnold $(2002,4)$ defines the empirical tradition as the source of the historical narrative which attempts to "order facts" by "letting them speak for themselves."

\footnotetext{
* Faculty of Fine Arts, Akdeniz University, Antalya, TURKEY.
}

\section{INTRODUCTION}

For a long time the historiography of Roman atrium house (2) has been based upon textual descriptions derived from Vitruvius (Mau, 1982, 2530). The texts of Vitruvius (1960), which reflect the theoretical and practical issues of architecture from the viewpoint of the ancients, give prescriptions about the ideal dimensions and construction methods for the houses. Studies on Roman atrium houses uncritically recognized the validity of these prescriptions and interpreted archaeological evidence from this viewpoint (Mauiri, 1953). It has been thought that spatial configurations of the atrium houses were physical reflections of the Vitruvian principles (Boëthius and Ward-Perkins, 1970). This deductive approach imposed preconceived typological features into archaeological material.

Contemporary developments in architectural historiography and archaeology, however, indicate that domestic architecture of the ancients was guided by environmental parameters and practical requirements rather than textual prescriptions (Jansen, 1991; Allison, 2001). Since the last decades of the 20th century, spatial information has gradually been more valuable for understanding the determinants of spatial configuration (3). Many scholars working on the Roman domestic space have begun to give more reference to spatial analysis (Allison, 2001; Wallace-Hadrill, 1997). The incorporation of new material evidence through more careful archaeological analysis has challenged the conventional framework. As a result the accuracy of Vitruvius' text in reflecting the historical reality has been questioned. The critical review of the atrium house is marked by the rise of empiric inductive method (4) which derives the general principles through scrutinized analyses of cases. This new approach replaces the idealist deductive method which forged the implications of material evidence for rendering them compatible with Vitruvian texts.

In this framework the roof structure of the atrium is an issue where contemporary interpretations of material evidence are at odds with 
Vitruvius' textual definitions. Material evidence yields the acquisition of three dimensional architectural forms in the context of environmental problems and practical solutions while Vitruvian text is based upon two dimensional typological preconceptions. Relying on the Vitruvian text, established deductive historiography argued that atrium house was a type reflecting the "Italic" rather than the "Greek" characteristics of architecture (Vitruvius, 1960). It was assumed that the original atrium-house was roofed and open atria emerged later due to "Hellenistic" influence. This argument was uncritically adapted to the three dimensional conceptions of the atrium's roof structure.

Established architectural historiography concerning the roof structure of the atrium-house requires a critical review. Material evidence indicates that alternative spatial configurations where atria are "open" and "closed" are possible. It is clear that, in contrast to conventional typology, these schemes are not stages of a chronological evolution. They coexist in certain historical periods as results of functional requirements (Wallace-Hadrill, 1997, 229 236). In addition, the terms "open" and "closed" oversimplify the spatial richness of the atrium houses. For a more comprehensive understanding of atrium house, these terms should be reconsidered in depth and from architectural perspectives. The degrees of "open" and "closed" should be rediscovered in order to determine functions of spaces, light and shadow values, structural system and the relations between all these architectural variables. This study explores the contemporary knowledge on the atrium houses in terms of the relations between the roof configuration and functional layout by proposing an alternative reading of the atrium house from architectural perspectives.

\section{ATRIUM HOUSE AND ITS ESTABLISHED HISTORICAL NARRATIVE}

\section{Atrium and Atrium-House}

The Roman provincial settlements of Pompeii and Herculaneum are the basic sources of available material evidence on Roman domestic space. These cities provide the most substantial information on Italic and Hellenistic period domestic architecture from the 4th century BCE to the time of the eruption of Vesuvius in CE. 79 (McKay, 1998, 30). The analysis of the settlement pattern in Pompeii indicates that the central space of each dwelling unit, which is called "atrium", had a focal importance in the total fabric of the built environment. The atria, which were the chief room of the house, constituted hollows in the settlement layout. Thus the ancient Roman authors Marcus Terentius Varro (c. 116-27 BCE.) and Marcus Vitruvius Pollio (c. 80-15 BCE.) name the atrium as cavum aedium, which stands for the "hollow of the house" (Robertson, 1969, 302).

Varro defined cavum aedium (hollow of the house) as "the roofed-over area inside the house walls which is left open for the use of everyone". This definition implied that the atrium was "a waiting room designed to receive and accommodate clients and visitors". Both Varro and Vitruvius regarded the atrium as an Italic characteristic. Varro stated that the Romans derived the atrium, both as a term and spatial convention, from the Etruscan settlement of Atria in the Po valley (McKay, 1998, 16). Vitruvius (1960), on the other hand, uses "atrium" as a synonym for Varro's cavum aedium. Although Vitruvius does not argue that the atrium was an Etruscan legacy from the city of Atria, he uses the adjective Tuscan in his interpretation of the types of atrium (McKay, 1998, 16). For Vitruvius, the atrium was an 
architectural characteristic peculiar to the Etruscans and Romans and it was unknown to the Greeks (Robertson, 1969, 302).

Due to the central importance of the atrium in the spatial organization of the built environment, the dwelling unit is called the "atrium-house," which is widely recognized as an architectural type associated with the ancient Italic culture (Figure 1). Scholars have agreed upon a common description of atrium-house, which is reflected in architectural history surveys.

"The earliest Italic scheme is the single-storey family domus - an inwardlooking, cool, and quiet house tightly organized around a core space called the atrium. Usually sky-lit, with a corresponding catch basin sunk in the pavement and hooked up to a cistern below, this central room held the shrine of the house gods (lalarium) and portrait busts of the owner and his ancestors. An entrance vestibule, the atrium, and a main room called tablinum_which was opened to a back garden were all arranged in a straight line. This axis of alternately light and dark spaces was flanked by symmetrically arranged rooms" (Kostof, 1985, 197-9)

This "Italic" scheme is contrasted with the loose organization of the "Greek" house (Kostof, 1985, 197-199). By illustrating the Roman domestic typology through "the House of Sallust in Pompeii" (Pre-Roman phase, 3rd century BCE), Kostof identifies two distinguishing characteristics of the atrium-house: "a feeling for inwardness" and "highly regimented composition that distinguishes Roman layouts from Greek and Hellenistic ones even at their most formal".

\section{The Established Historical Narrative of the Atrium-House}

The concepts of atrium and the atrium-house are established primarily on textual sources. The established historical narrative of the atrium-house has favored texts and preconceived typology at the expense of the material evidence. It is a matter of question if the material evidence verifies the conventions. Typology is constructed by the juxtaposition of the ancient texts with two dimensional plan organizations. However the language of the material evidence is three dimensional and spatial configurations are widely shaped by environmental parameters. In spite of this discrepancy, the typological diagnosis of the atrium as an Italic feature affected the three-dimensional reconstructions of the atrium-house.

Atrium's roof structure is an appropriate field for testing the accuracy of the conventional historiography through material evidence. It is argued that the atrium was the chief room of the house which regulated the rhythm of alternating light and dark spaces throughout the symmetrically arranged rooms (Kostof, 1985, 197-9). Then how was the three-dimensional arrangement of this layout and how was this rhythm of light and dark reflected by the roof structure? How did the ancients arrange the correspondence of the atrium's "sky-light, catch-basin" and "cistern" in the three dimensional configuration? When the established historical narrative of the atrium-house is taken into account in terms of these architectural questions it can be realized that Vitruvian text was taken as the principal reference in an uncritical manner because contemporary research in Pompeii indicates that important data derived from material evidence have been overlooked for a long time (Wallace-Hadrill, 1997).

The main reasons for the erroneous conception of the atrium's roof system are the straightforward suggestions derived from the typological evolution pattern accepted by the conventional historiography (Figure 1). 
5. This evolutionary pattern originating from the simple atrium-house and leading to a combination of the Italic atrium with the Hellenistic peristyle reflects "the coherence of linearity" which is regarded by Arnold (2002, 4) as the basic component of the conventional historical narrative. Arnold states that coherence is seen as the "essential part of the narrative in order for it to work as a story." and argues that the "coherence of linearity is a selective process that requires the exclusion of material and the imposition of a unity on a disparate set of historical events or circumstances." She claims that through this exclusive process, the narrative acquires a "built-in notion of progress," which is rather fictional than real.
Figure 1. Proposed evolutionary development of the atrium-house: testudinate house form as an origin, Italic atrium house as an archetype and the addition of Hellenistic peristyles (drawn by author).
At the earlier phase of the proposed evolution, the Italic houses involved the characteristic atrium conforming to Vitruvian definition and the later phase peristyles were added into the original atrium-house due to Hellenistic influence (5) (Figure 1). In terms of the roof system, it has been argued that the Italic atrium and the Hellenistic peristyle coexisted within the same building envelope but retained their original characteristics (Boëthius and Ward-Perkins, 1970). In other words, it has been proposed that the atrium, which was unknown to the Greeks, always followed the Etruscan tradition of elaborate roofs which made it possible to construct a skylight (compluvium) without any need for vertical posts (Figure 2a).

It is known that the oldest houses in Pompeii dating from the 4th and 3rd century BCE reflects the basic atrium-house typology given by Vitruvius (Vitruvius, 1960; Robertson, 1969, 302). Vitruvius associates the atirum's roof with the elaborate wooden roofing tradition of the Etruscans. He states that there were no columns at the corners of the impluvium (the catch-basin on the floor) to support the frame of the compluvium (skylight) (Vitruvius, 1960; McKay, 1998, 17). In Vitruivan definition, the roof of the Tuscan atrium was supported on two deep wooden beams spanning the entire length of the room and framing the long sides of the compluvium while the short sides were framed by secondary beams supported by the main beams. Departing from the resultant rectangular frame of the compluvium, the roof sloped upward and outward in four directions.

There are further arguments which accentuate Vitruvian association of the atrium with the Etruscan origins. Boëthius and Ward-Perkins (1970, 152) argue that Vitruvius and Varro were right in deriving the cava aedium (atrium) from the Etruscans because the main features of the atrium could be traced back to the archaic Etruscan architecture. The authors compare the Late Republican-Roman atrium-houses with archaic Etruscan tombs and argue that both typologies were strictly axial and symmetrical and they were accessible by a forecourt and lobby (Boëthius and Ward-Perkins, 1970:

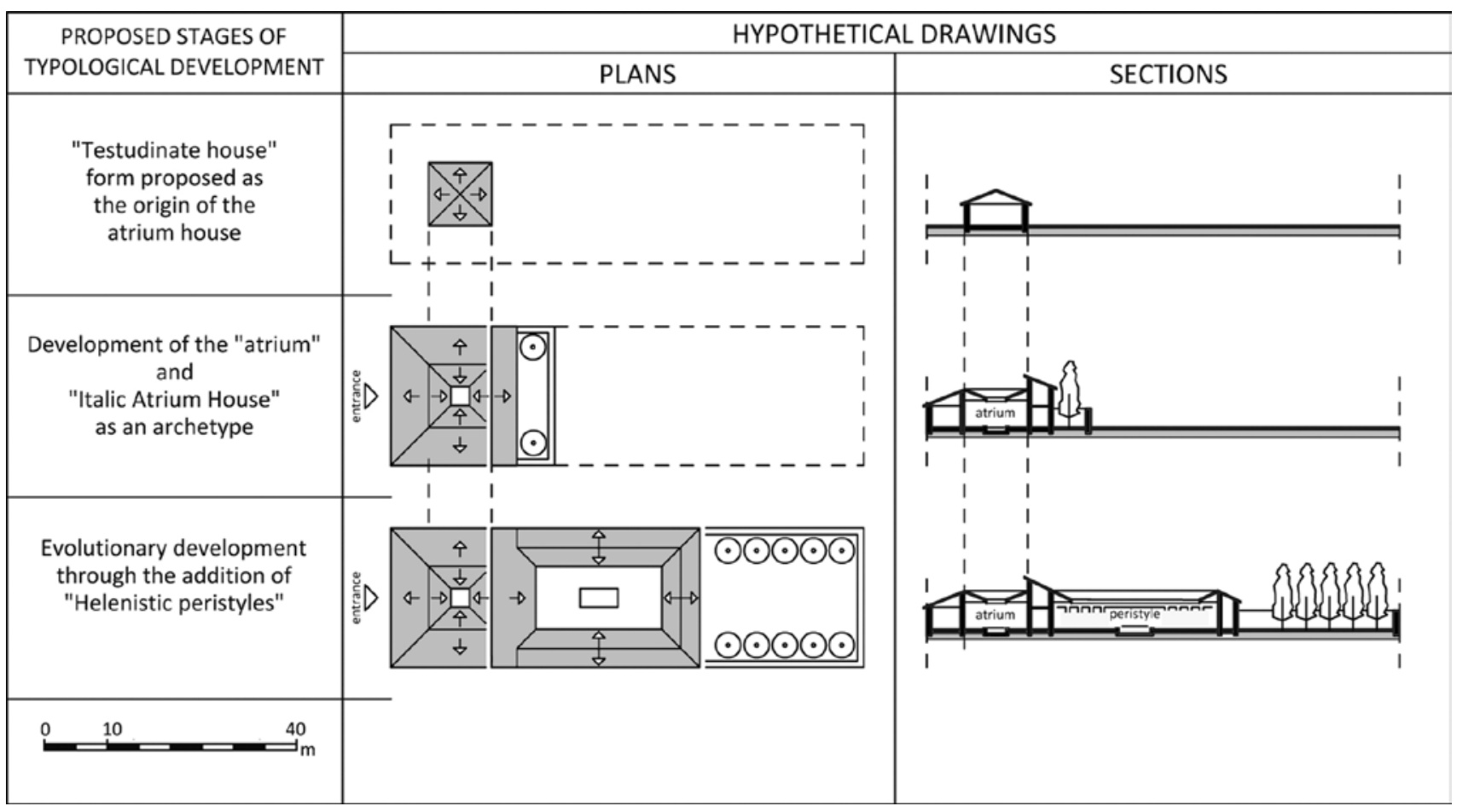




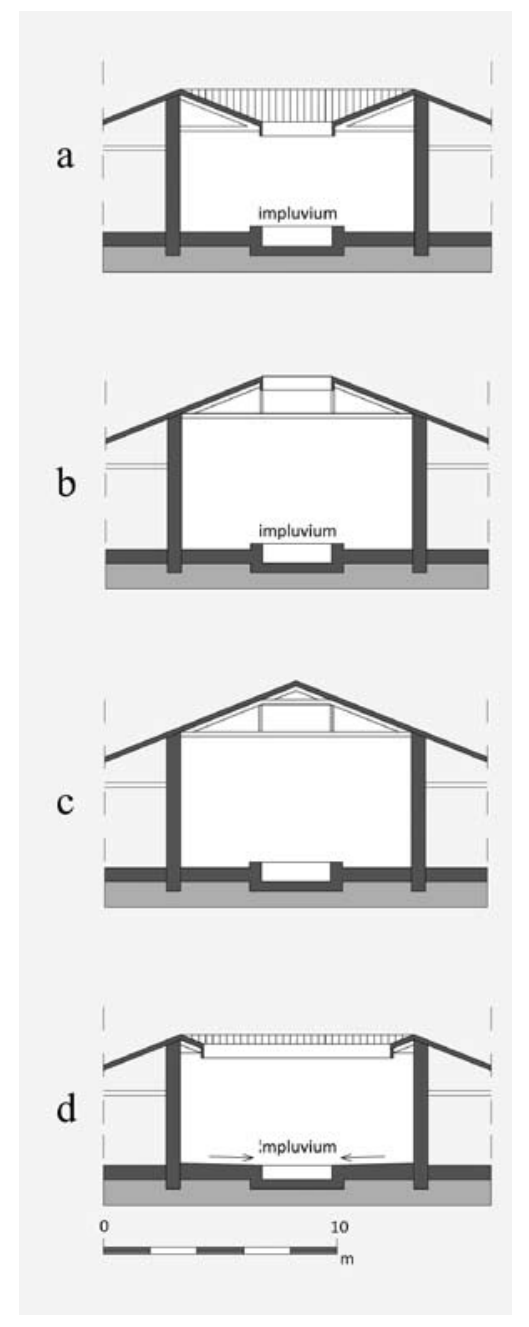

Figure 2.

a- A hypothetical section of the impluviate (compluviate / inward sloping) roof of the atrium. (partial drawing) (drawn by author).

b- A hypothetical section of the impluviate (displuviate / outward sloping) roof of the atrium. (partial drawing) (drawn by author).

c- A hypothetical section of the testudinate atrium form. (partial drawing) (drawn by author).

d- A hypothetical section of the atrium completely open without any roof (partial drawing) (drawn by author).

6. Patroni, on the other hand proposed another evolutionary lineage connecting the roofed atrium into Italic origins (McKay, 1998: 17-18). Patroni proposed an archetypal Italian farmhouse with deep overarching eaves familiar from the architecture of the early Etruscan temples. These eaves would project over the court and would eventually result in a court becoming the atrium with a rectangular skylight (compluvium) in its roof.
152-3). They also state that during the last centuries BCE peristlye emerges as an indication of the "victorious Greek taste" and a new combination was handed over to the Imperial Rome (Figure 1) (6).

There is no certainty concerning the proposed continuity between the archaic Etruscan tomb and the Late-Republican atrium-house. There can be many objections to the typological evolution pattern. First of all these typologies are detached in terms of chronology. Secondly, there is no tangible evidence to legitimize these proposals. Lastly domestic architecture is determined much more by local climate and other practical requirements than by preconceived typologies conforming to ethnic origins.

Different proposals of typological evolution shared a common argument of the roofed atrium whose slope changed over time due to certain functional requirements. For instance, McKay $(1998,22)$ argues that during the earlier phase the atria were closed by outward sloping roofs. This scheme was inherited from the farmhouse and from less crowded settlements where cisterns were located outside the walls to collect rainwater from the testudinate roof system (Figure 2c). However, later, as settlements became more populated the slope of the atrium's roof was reversed in order to ensure the household's constant supply of easily accessible clean water. In this phase the impluvium (catch basin on the floor) developed beneath the compluvium (skylight) (Figure 2a).

Vitruvius distinguishes five types of cavum aedium (atrium), which correspond to five alternative methods for roofing the atrium: the Tuscan, the Corinthian, the tetrastyle, the displuviate and the testudinate (Vitruvius, 1960; Robertson, 1969, 302). According to him, the Tuscan, the displuviate and the testudinate types are interrelated. For defining the cava aedium tuscanica Vitruvius firstly refers to impluvium, which is the "square basin in the middle of the atrium with reservoirs receiving rainwater from an open space in the roof, which slopes inward". In the Vitruivan terminology the Tuscan roof system corresponds to the compluviate (inward sloping) configuration (Figure 2a) where water is stored by the impluvium. Another option was the displuviate roof (Figure $\mathbf{2 b}$ ) which retained the square opening above the impluvium but being outward sloping. The testudinate roof system, on the other hand, was totally closed (Figure 2c) (Wallace-Hadrill, 1997, 220). Corinthian and tetrastyle are other alternative arrangements for the support of the beams of the compluviate (inwardsloping) which might rest on columns at the corners of the impluvium.

The established architectural historiography of the Roman atrium-house insisted that the "Italic atrium" was roofed following one of the Vitruivan models while the "Hellenistic peristyle" was an unroofed addition to the original atrium-house. According to the Vitruvian model of the atriumhouse, which had been the principal historical reference until the last decades, the atrium was definitely covered by a roof. Being roofed was seen as a defining feature of the "Italic" architectural character since this quality distinguished it from the Greek - Hellenistic influence which was introduced later through the addition of unroofed peristyles (Figure 1). Because of this preconception atrium has been regarded as a roofed space being either impluviate (with opening) or testudinate (closed). The impluviate roof had two variations which were the inward sloping compluviate (Tuscan) system and the outward sloping displuviate system. 
7. This notion of architectural progression necessitating the roofed atrium is based upon the Hegelian notion of historical evolution (Fernie, 1995, 13). Historiography creates a narrative which proceeds from empirically validated facts but requires imaginative steps to achieve a coherent story. (Arnold, 2002). Historical narrative, therefore, cannot be accomplished without any unifying principle, but necessitates a mental construction that relates the fragments. (Fernie, 1995, 13) At this point the relevance of this "mental construction" to the historical reality is debatable because typological classification becomes an end in itself rather than a tool (Ridgway, 1986, 9). Therefore critical inquiries into the established historical narrative have to deal with theoretical models that have been built up by generations of scholars who had transferred their own preconceptions onto the classical past in an uncritical manner (Nevett, 1999, 12)

8. Wallace-Hadrill (1994) furthermore discerns the underlying social flows pertaining to the concepts of gender, privacy and social status within the material remains of the atrium-house.

\section{MATERIAL EVIDENCE AND THE ROOF STRUCTURE: A CRITICAL INQUIRY INTO THE ATRIUM HOUSE}

It is seen that the established historical narrative of the atrium-house is the product of an archaeological idealism that forges the material evidence into a coherent evolution of architectural types (7). The conventional typology of the atrium-house is questioned by several specialists working on the field.

"Classical archaeologists are fond of constructing typologies, and they can serve as a powerful tool for recognizing and identifying new specimens. But before social historians are sucked into the system of categorization, we must ask at what level the typology exists: is it merely a convenient way for the modern observer to sort the evidence, or does it reflect distinctions of which the ancient user was conscious, and which were embedded in the structures of society?" (Wallace-Hadrill, 1997, 222)

When Roman domestic space is taken into account such critical inquiries are very recent. The study of Roman domestic architecture, from the 18th century onwards, is confined within the limits of description, classification and typological survey and that the social implications of architecture and the indications of material evidence have only recently been taken into account (Scott, 1997, 53).

Critical inquiries into the history of domestic space become possible by the empirical investigations which challenge the traditional art historical approach based upon uncritical idealism (Stieber, 2006, 178). Concurrent to the rise of empirical investigation, comes the gradual rise of interest in the reassessment of the material evidence (Meeks, 1942, 21; Allsopp, 1970, 105; Ridgway,1986, 22; Stieber, 2006, 172-5). In the light of these discussions, the Roman domestic space assumed a renewed popularity owing to the increasing accumulation of the material evidence and its treatment with improved technological methods such as stratigraphic testing.

A significant representative of the critical review of the Roman-atrium house from the viewpoint of material evidence is the interpretation of Andrew Wallace-Hadrill. His interpretation of the alternative roof structures covering the atrium in houses of Cosa and Pompeii (WallaceHadrill, 1997) is taken as an example for the incorporation of new data into the historical narrative of the Roman atrium-house.

Wallace-Hadrill's (1994) approach represents empiric inductive method. He explores the rich potential of the houses of Pompeii and Herculaneum to offer new insights into Roman social life and combines archaeological evidence with Roman texts. He challenges the typological orthodoxies established around the Roman atrium-house (8). Through the analysis of the remains of over two hundred houses, Wallace-Hadrill reveals the remarkable discrepancies between the established historiography and the overlooked material evidence. He (1997) argues that the Vitruvian atriumform is not verified by the material evidence. Repudiating the analysis of the Roman atrium-house as a rigid type, he argues that scholarship had restricted itself to the textual evidence of the Vitruvian atrium-house. The interpretations of Vitruvius offer a particular atrium-form whose features cannot be verified by the material evidence.

For Wallace-Hadrill $(1997,220)$, the Vitruivian model asserts that the "impluviate roofed court" is "the hallmark of traditional Roman architecture." In this way, the presence of the Vitruivian roofed atrium was taken as a criteria according to which the "Greek" and "Roman" 
houses can be distinguished from each other. Conventional typology of the atrium-house was based upon the underlying assumption that the central court (atrium) of a typical Roman house had to be roofed and that "the link between impluvium and compluviate roof-line" (Figure 2a) was the characteristic architectural section of the "true" atrium-house (WallaceHadrill, 1997, 223). This section where the rainwater was transferred to the impluvium through the compluviate roof was thought to typify the atriumhouse in spite of the fact that there was no clear material evidence to justify this assumption.

Due to the adherence to this assumption, generations of scholars insisted on thinking that any court without an impluvium had a testudinate roof (Figure 2d). The position of cisterns, drains at ground level and the traces of roof-beams and tiles at the upper level were not investigated. It was accepted that testudinate roof was the original layout and compluviate roof developed later (Figure 1). Escebach's interpretation into the Casa di Ganimede reflects this evolutionary hypothesis (Wallace-Hadrill, 1997, 226). Here, stratigraphic analysis revealed three atrium levels. The first one was the impluvium level of $79 \mathrm{CE}$, which is the explosion date of Vesuvius. Beneath the first layer, there is a second layer indicating an older impluvium. Below these there is a third layer which is a beaten earth floor without any trace of an impluvium. Departing from this information Escebach argued that the lowest and thus the oldest level was covered with a testudinate roof and the other phases had displuviate roofs. The possibility of an open courtyard (Figure 2d) was never considered.

Escebach's approach conformed to the construction of an evolution which places at the origin the testudinate layout as an Italic character. For Hoffmann $(1979,110-3)$ the testudinate type was the origin of all Roman houses, the compluviate form was a later development for responding the need for light inside the house within the dense urban layout (WallaceHadrill, 1997, 227). In his Architectural History of Pompeii, Richardson (1988) supports this view further by arguing that testudinate not only stands for a roof form but also represents a house type. This "testudinate house" was obtained solely by covering the atrium with an outward-sloping roof. There were no side rooms organized around the atrium. This "original" form was modified later by the addition of side rooms making atrium the central space with a compluviate roof developed in order to increase the amount of natural light coming into the house (Figure 1).

The same hypothesis was also imposed to the famous Casa del Chirurgo in Pompeii, which had been a significant example for the historiography of the Roman atrium-house. Despite substantial material evidence indicating the presence of an open atrium in the Casa del Chirurgo, the research undertaken until the 1990s reflects a biased opposition (Wallace-Hadrill, 1997, 223-8). Although a testudinate atrium of this size was not imaginable due to structural problems of the roof, the same typological model was insisted because a complete enclosure (testudinate form) was thought to be the only alternative to a compluviate roof.

Wallace-Hadrill criticizes the "evolutionary" models of the atrium-houses which were proposed by Patroni and Maiuri. Based on these models, he also opposes the "recent tendency to see the testudinate atrium without side rooms as an 'original' form of the impluviate atrium with siderooms." He argues that accepting "a complex historical reality 'emerging' from one simple ideal is ahistorical" and that the evolutionary models are unreliable and also ideologically and nationally biased. Wallace-Hadrill $(1997,236)$ 
verifies his argument by demonstrating that the latest housing survey from the 8th to 3rd century in Apulia and Lucania contains "a wide range of available types at every period". For him, the insistence on either impluvium or testudinate system was due to nationalistic bias which distorted the implications of the material evidence for the sake of deriving an ancient Italic tradition of domestic space independent from Greek and Hellenistic patterns (Figure 1). Because of this biased theoretical framework "the idea of the open court was simply lost from circulation" without any logical explanation (Wallace-Hadrill, 1997, 227).

The theoretical background of Wallace-Hadrill's "rethinking" of the Roman atrium-house reflects an opposition to the conception of the atrium and its roof system as a typological feature legitimizing genetic codes of "Italic" architecture. Opposing the notion of atrium-house as a fixed typology whose architectural features had been based upon the Vitruvian text, Wallace-Hadrill suggests a critical analysis of the roof structure of the atrium by referring to the material evidence and the newly developing techniques of stratigraphic testing. He argues that the association of architecture as a "social form" with "genetic evolutionary forces" is quite weak because this hypothesis is "founded on very little stratigraphicallycontrolled evidence" (Wallace-Hadrill, 1997, 220).

Wallace-Hadrill (1997, 219-40) also considers the discovery of new archaeological evidence from the provincial sites like Cosa and Fragellae as a chance to envisage Roman domestic space within a broader geography beyond the conventional sites of Pompeii and Ostia. He analyzes the roof system of the House of the Skeleton at Cosa, which resembles a canonical atrium-house of the Pompeian type. In this example, despite the presence of an impluvium there is clear evidence for an unroofed atrium (WallaceHadrill, 1997, 228). The material evidence unmistakably proves the open atrium because the pavement indicates clear traces of a drip line around the borders of the atrium and in some parts immediately outside the side spaces (tablinum and ala). An open atrium with an impluvium indicates that in some Roman houses water could fall on the surface of an open courtyard and then was transferred to the impluvium. Therefore, in contrast to the general belief, impluvium was not necessarily the first architectural component that the rainwater contacted.

In spite of the sound material evidence proving the coexistence of open atrium and compluvium the excavators of the House of the Skeleton were reluctant to accept this historical reality. They thought that this was an exception and hence tried to explain it as an unexpected change in plan or interruption of the construction process (Wallace-Hadrill, 1997, 229). Wallace-Hadrill argues that such explanations are unsatisfactory because the architectural scheme of the house reflected a consciously planned architectural layout incorporating perfect squares within squares (Figure 3).

The off-centered arrangement of the square impluvium with respect to the square formed roof line demarcating the atrium was so consciously done that, on the NE and SE sides, a covered walkway or a semi-closed space came out as a transitional zone between the open atrium and closed side spaces. Meanwhile on the SW and NW sides the rooms also directly opened to the atrium. In terms of function and social utility this spatial layout was very logical. The "private" side rooms used by the household were protected from the weather conditions by the covered walkway while the "public" side rooms which were used less frequently, were highlighted 
Figure 3. Hypothetical plan indicating the light and shadow effects associated with the more public and more private side rooms around the roofless atrium (partial drawing) (drawn by author).
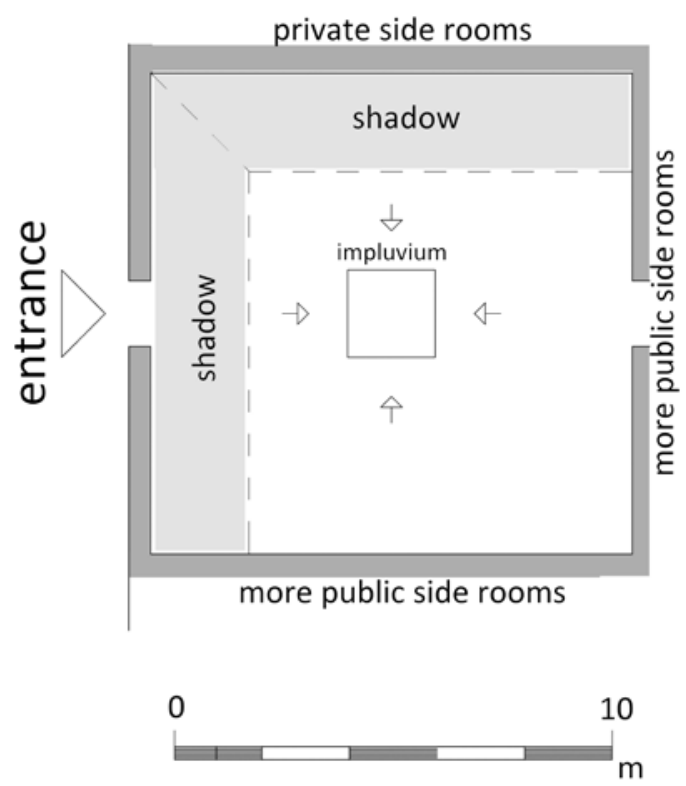

9. This spatial analysis can be reconsidered in the light of Stieber's $(2006,179)$ proposal for "another history of space" which "emerges from testing theory empirically, that leads in turn to the revision of theory, and deepens the understanding of both theory and the built environment." In this respect, WallaceHadrill's contribution may be regarded as a response to Stieber's $(2006,179)$ call for "theoretically informed, empirical research that recognizes the social agency of spatial form, the active social role of purely spatial reality of architecture, a spatial reality that operates through its visuality."

10. The repudiation of the historicity of typology is also stressed by Toner who states that "labels belonging to the historian's tool-box" should not be complicated with the "realities of the Roman empire." (Toner, $1995,5-7)$ His inquiry that stemmed from the simple question of whether the atrium was a roofed space or not prompts the search for the historical truth and this difficult task is defined by Toner as the "insoluble quandary of the historian" who tries to make a "historical translation." by direct exposure to sun. In this sense the light and shadow effects were perfectly integrated to the functional requirements (9) (Figure 3).

If the preconceptions established around the atrium are set aside, it can be realized that the House of Skeleton with an open atrium is a perfect reconciliation of two conflicting functional requirements: the need for light to illuminate the rooms and the need for protection from undesired weather conditions (Wallace-Hadrill, 1997, 229). The House of the Skeleton clearly indicates that the spatial configuration of the atrium-house was shaped by practical requirements, climatic conditions and environmental parameters. Thus the typological patterns stimulated by ideological preconceptions only exist in the mind of the interpreter and these have nothing to do with the historical reality (10). In this sense, Wallace-Hadrill's interpretation of the House of the Skeleton illustrates the success of empirical investigation and the spatial analysis at the failure of out-dated evolutionary models.

This review of the atrium's spatial configuration makes it possible to propose an architectural analysis of the atrium from functional perspectives. Atrium's roof should be regarded as a water management system shaped as an environmental response to the functional requirements such as the collection and management of rain-water and the illumination of the surrounding rooms. A new conception of the roof free from Vitruvian patterns should be developed since the roof not only protects from bad weather but also collects rainwater and directs it into cisterns in the most efficient manner (Wallace-Hadrill, 1997, 231).

The available method for revealing the configuration of water management systems relies on an analysis of the material evidence. Wallace-Hadrill $(1997,231)$ argues that old excavation reports are inadequate for tracing the water management system since the authors did not investigate the material evidence from this viewpoint. Therefore new excavations compatible with the stratigraphic analysis are needed. The analysis of the water management system by going back to the material sources is 
advantageous since the components of the system compose of sub-surface elements which are archaeologically well-preserved and their changes can be followed through successive strata. Although this type of material evidence is easily accessible, it did not receive enough attention by the previous excavators. Wallace-Hadrill $(1997,232)$ argues that the reason for being less informed about the water management system of the atriumhouse is "not the difficulty of finding evidence, but failure to appreciate its significance."

The case of the House of the Skeleton in Cosa and the theoretical conclusions derived from this example constitute an evidentiary basis to introduce a critical review into the atrium-houses of Pompeii. For Wallace-Hadrill $(1997,233)$ the Casa delle Forme di Creta excavated by D'Ambrosio and De Caro offers a perfect ground for investigating the presence of an open atrium in Pompeii. In this example there are three distinct stratigraphic layers which reveal a down-pipe system justifying "a roof system sloping towards the atrium but not extending over it." In other words, Wallace-Hadrill identifies the traces of a drainage system that would only be "compatible with atria with inward sloping roofs that extended no further than a walkway sheltered by overhanging eaves." The analysis of Casa delle Forme di Creta reveals that open atrium is compatible with an intricate system of water management and storage. Impluvium then is a component of this overall water management system which, according to its role, can be a part of an open atrium (Figure $\mathbf{2 d}$ ) as well as a compluviate roof system (Figure 2a) (Wallace-Hadrill, 1997, 231).

Neither atrium nor impluvium are fixed typological features as imposed by the conventional historical narrative and the discussion of atriums' roof system in isolation from environmental parameters and functional requirements does not make any sense. The atrium and its roof should be interpreted together with the adjoining spaces in the framework of its overall performance in a certain environmental context. The spatial configuration of the atrium should be seen as a practical solution to local environmental requirements rather than the justification of a fixed Italic identity manifesting itself regardless of the local context.

\section{CONCLUSION}

The discussion of the atrium and its roof system illustrates the theoretical transformations that have taken place in the study of Roman domestic space starting from the last decade of the $20^{\text {th }}$ century. During this period, critical inquiries have challenged the established historical narratives of the atrium-house. The critical reviews of the Roman atrium-house from architectural perspectives rely on an empiric collection of data and reorganization of this data according to the functional and environmental contexts of the historical period under investigation. The incorporation of stratigraphic analysis, furthermore, enables to develop a variety of conclusions.

Although the conventional historical narrative of the atrium-house discussed atria in isolation from environmental parameters and functional requirements, neither atrium nor impluvium are fixed typological features. Wallace-Hadrill's $(1994 ; 1997)$ studies have shown that the atrium and its roof should be interpreted together with the adjoining spaces in the framework of its overall performance in a certain environmental context. 
Contrary to the conventional narrative, then impluviate atrium is not a defining feature of the atrium-house. "The gathering of rooms, large and small, open and closed, around a central court, whether roofed or not" characterizes the Roman atrium-house (Wallace-Hadrill, 1997, 223).

General conclusions can be derived from this particular discussion of the Roman atrium-house. The spatial configuration of the domestic space in both Ancient Roman period and in any other culture should be seen as a practical solution to local environmental requirements rather than reflections of fixed ethnic identities manifesting themselves regardless of the local context. Therefore the architectural components of the historical built environment should be seen as the products of the effort to resolve the practical and environmental problems of daily life. The actual role and meaning of these components in their historical context cannot be understood by considering them as the defining features of typologies. Therefore the material evidence reflecting the solutions for the practical problems becomes an important source for deciphering the spatial configuration of the ancient dwellings.

\section{BIBLIOGRAPHY}

ALLISON, P. (2001) “Using the Material and Written Sources: Turn of the Millennium Approaches to Roman Domestic Space," American Journal of Archaeology (105) 181-208.

ALLSOPP, B. (1970) The Study of Architectural History, Praeger Publishers, Inc., New York.

ARNOLD D. (2002) 'Reading the Past: What is Architectural History?,' Reading Architectural History, Routledge, London and New York; 1-13.

BOËTHIUS, A. and WARD-PERKINS, J.B. (1970) Etruscan and Roman Architecture, Penguin Books, Baltimore, Maryland.

FERNIE, E. (1995) "Introduction: A History of Methods", Art History and Its Methods: A Critical Anthology, Phaidon, Hong Kong; 10-21.

HOFFMANN, A. (1979) “L'architettura," Pompei 79 (F. Zev. eds.) Naples; 97-118.

JANSEN, G.C.M. (1991) Water and Sanitation Systems in the Houses of Herculaneum, Meddelingten Nederlands Instituut te Rome (50) 145-66.

KOSTOF, S. (1985) A History of Architecture: Settings and Rituals, Oxford, Oxford University Press, NY.

MAU, A. (1982) Pompeii, Its Life and Art, tr. by F.W. Kelsey (originally published in German in 1902), Caratzas Brothers publishers, New Rochelle and New York.

MAIURI, A. (1953) Pompeii, tr. by V. Priestley, La Libreria dello Stato, Rome.

MEEKS, C. (1942) 'The Teacher of Architectural History in the Professional School: His Training and Technique,' Journal of the America Society of Architectural Historians (2) 14-24.

McKAY, A.G. (1998) Houses, Villas and Palaces in the Roman World, The John Hopkins University Press, Baltimore and London.

NEVETT, L. (1999) House and Society in the Ancient Greek World, Cambridge University Press, Cambridge. 
RIDGWAY, B.S. (1986) 'The State of Research on Ancient Art,' in The Art Bulletin March 1986, v: LXVIII, n:1; 7-23.

RICHARDSON, L. Jr. (1988) Pompeii, An Architectural History, The Johns Hopkins University Press, Baltimore and London.

ROBERTSON, D.S. (1969) Greek and Roman Architecture, Cambridge University Press, Cambridge.

SCOTT, S. (1997) The Power of Images in the late Roman House, in R.Laurence and A.Wallace-Hadrill eds. Domestic Space in the Roman World; Pompeii and Beyond, Journal of Roman Archaeology, (Supplement 22) Providence, Rhode Island.

STIEBER, N. (2006) Space, time and architectural history, in Rethinking Architectural Historiography, D.Arnold, E.A.Ergut and B.T.Özkaya eds, Routledge, London and New York; 171-82.

TONER, J. P. (1995) Leisure and Ancient Rome, Cambridge: Polity Press

VITRUVIUS, M. (1960) The Ten Books on Architecture (tr. by M. H. Morgan), Dover Publications, NY.

WALLACE-HADRILL, A. (1997) "Rethinking the Roman Atrium House" in R. Laurence and A. Wallace-Hadril eds. Domestic Space in the Roman World; Pompeii and Beyond, Journal of Roman Archaeology Supplement 22, Providence, Rhode Island, 219-40.

WALLACE-HADRILL, A. (1994) Houses and Society in Pompeii and Herculaneum, Princeton University Press, Princeton.

Alındı: 17.06.2010, Son Metin: 21.06.2012

Anahtar Sözcükler: atrium; Roma konut mimarisi; mekân kurgusu; çatı; mimarlık tarihi yazımı; Pompeii.

\section{ROMA ATRİUM EVİ İÇIN ELEŞTİREL BİR DEĞERLENDİRME: FIZİKSEL KANITLARIN “ATRIUM” ÜZERINNDEN OKUNMASI}

Roma konut mimarisinde öne çıkan yapı tipi olan atrium evi, uzun bir süre boyunca Vitruvius'un metinlerine dayalı yazılı tanımlamalar çerçevesinde incelenmiştir. Buna karşın son yıllarda Roma atrium evi kapsamındaki tarih yazımı arkeolojik buluntuların artışı ve bu kaynakların değerlendirilmesindeki teknolojik gelişmeler ile birlikte dönüşüm geçirmektedir. Yazılı kaynaklara dayalı tanımlamalar yerini mimarinin fiziksel kaynaklarına eğilen ve mimari elemanlar ile birlikte evin mekânsal kurgusunu dikkate alan eleştirel yaklaşımlara bırakmaktadır. Yirminci yüzyıl sonundan günümüze kadar süregelen birçok araştırma ile konut mekânlarının etrafında kümelendiği merkezi mekân olan atriumun mekânsal kurgusunu algılama çabasında salt yazılı kaynakların yetersizliği ortaya konmuştur. Roma atrium evinde tarihsel okumaların fiziksel kanitlar ile desteklenmesi gerekmektedir.

Atrium çatı kurgusu güncel arkeolojik veriler ve yorumlama araçları 1şığında incelendiğinde atriumun üstünün "açık" veya "kapalı" olduğu alternatif şemaların olanaklı olduğu görülmektedir. Atrium evindeki yaşamın daha doğru bir şekilde anlaşılabilmesi için "açık" ve "kapalı" tanımlamaları kendi başlarına yeterli değildir. Bu veriler mimari açıdan derinlemesine incelenmeli ve açıklık ile kapalılığın derecelerinin ne olduğu, bu özelliklerin mekânın işlevi, ş̧ık-gölge değerleri ve yapı sistemi 
üzerindeki etkileri ortaya konmalıdır. Bu çalışmada atriuma dair güncel arkeolojik bilgiler çatı örtüsünün açıklık-kapalılık dereceleri kapsamında ve mimari açıdan incelenmekte ve Roma konut mimarisindeki mekân kurgusunun zenginliklerini ortaya koyabilecek bir tarihsel okuma önerilmektedir.

KEMAL REHA KAVAS; B.Arch., M.Arch., Ph.D.

Assistant Professor at Architecture at Akdeniz University, Faculty of Fine Arts, Antalya. His research focuses on domestic space and environmental aesthetics. Received B.Arch (2002), M.Arch (2005) and Ph.D. (2009, History of Architecture) degrees from the Department of Architecture at METU. His Ph.D. Thesis won the 2009 "Thesis of the Year Award" of the METU Prof.Dr. Mustafa N. Parlar Association of Education and Research. krkavas@gmail.com 